\title{
Fungsi Bahasa Indonesia dan Fungsi Teks dalam Kehidupan Sehari-hari
}

\author{
Dzikrina Rahmah \\ Email: dzikir.rahmah26@gmail.com
}

Bahasa merupakan alat komunikasi yang diperoleh manusia sejak lahir. Penguasaan sebuah bahasa oleh seorang anak dimulai dengan perolehan bahasa pertama yang sering kali disebut bahasa ibu. Menurut Kridalaksana (dalam Suardi et al., 2019) , bahasa pada hakikatnya merupkan sistem lambang bunyi yang arbitrer yang digunakan oleh anggota kelompok sosial untuk bekerja sama, berkomunikasi, dan mengidentifikasikan diri. Menurut Chaer (dalam Diah \& Wulandari, 2015), Fungsi bahasa sebagai alat komunikasi manusia mencakup lima fungsi dasar, yaitu fungsi ekspresi, fungsi informasi, fungsi eksplorasi, fungsi persuasi dan fungsi entertainmen. Fungsi ekspresi mewadahi konsep bahwa bahasa merupakan media manusia untuk melahirkan ungkapan-ungkapan batin yang ingin disampaikan penutur kepada orang lain. Fungsi informasi adalah fungsi untuk menyampaikan pesan atau amanat kepada orang lain. Fungsi eksplorasi adalah penggunaan bahasa untuk menjelaskan suatu hal, perkara dan keadaan. Fungsi persuasi merupakan penggunaan bahasa yang bersifat mengajak atau mempengaruhi. Sedang fungsi entertainmen bahasa adalah penggunaan bahasa untuk menghibur, menyenangkan dan memuaskan batin. Kelima fungsi ini sangat mendukung proses pengembangan ilmu pengetahuan, terutama fungsi informasi dan fungsi eksplorasi.

Dari hasil penelitian tentang fungsi bahasa Indonesia sebagai alat komunikasi dalam kehidupan sehari-hari. dari 40 responden 32 orang (80\%) sangat setuju dan 8 orang (20\%) setuju bahwa dalam komunikasi bahasa digunakan sebagai alat untuk menyampaikan informasi. 21 orang $(52,5 \%)$ sangat setuju dan 19 orang $(47,5 \%)$ bahwa dalam berkomunikasi bahasa digunakan sebagai penyalur untuk mengungkapkan apa yang diinginkan dan bahasa menjadi modal bagi seseorang untuk beradaptasi dengan lingkungan yang baru. 14 orang (35\%) sangat setuju, 19 orang $(47,5 \%)$ setuju, dan 7 orang $(17,5 \%)$ tidak setuju jika bahasa Indonesia selalu digunakan dalam situasi formal. 15 orang $(37,5 \%)$ sangat setuju, 17 orang $(42,5 \%)$ setuju, 7 orang $(17,5 \%)$ tidak setuju dan 1 orang $(2,5 \%)$ sangat tidak setuju jika dalam berkomunikasi penggunaan bahasa Indonesia lebih banyak digunakan oleh masyarakat kota. 23 orang $(57,5 \%)$ 
sangat setuju dan 17 orang (42,5\%) setuju bahwa mereka dapat berkomunikasi menggunakan Bahasa Indoensia dengan baik dan benar secara lisan dan tertulis. 22 orang (55\%) sangat setuju, 17 orang $(42,5 \%)$ setuju, dan 1 orang $(2,5 \%)$ tidak setuju bahawa Bahasa Indonesia mendukung proses pengembangan ilmu pengetahuan, terutama fungsi informasi dan fungsi eksplorasi. 23 orang (57,5\%) sangat setuju, 15 orang (37,5\%) setuju, dan 2 orang (5\%) tidak setuju jika penggunaan bahasa Indonesia yang baik dan benar dipengaruhi oleh pemerolehan bahasa pertama atau bahasa Ibu. 13 orang (32,5\%) sangat setuju, 19 orang $(47,5 \%)$ setuju, dan 8 orang $(20 \%)$ tidak setuju bahwa mereka menggunakan Bahasa Indonesia saat berkomunikasi di media sosial.

Dalam wujudnya, bahasa selalu berbentuk teks. Adapun yang dimaksud dengan teks adalah satuan lingual yang mengungkapkan makna secara kontekstual. Di sini, istilah "teks" dianggap sama dengan "wacana", dan satuan lingual dapat berupa kata, kelompok kata, klausa, atau kumpulan paragraf. Apabila seseorang ingin mengungkapkan sesuatu, ia akan menggunakan bentuk teks tertentu. Dengan teks itu, ia akan mencapai tujuan yang diinginkannya. Agar teks itu dapat mewadahi dan menjadi sarana untuk menyampaikan tujuannya, ia berusaha agar teks itu mengandung bentuk-bentuk bahasa yang relevan. Bentuk-bentuk itu tidak lain adalah sistem linguistik yang ada di dalam teks tersebut. Apabila tujuan yang disampaikan berbeda, maka bentuk teks yang digunakan berbeda, dan bentuk-bentuk bahasa yang dipilih di dalamnya pun juga berbeda. Akhirnya, teks yang tercipta akan dapat mewakili seseorang tersebut, karena pada dasarnya sikap, gagasan, dan ideologinya telah disampaikan melalui tujuan yang diungkapkannya dengan memilih bentuk-bentuk bahasa yang relevan tersebut.

Dari hasi penelitian tentang fungsi teks dalam kehidupan sehari-hari, dari 40 responden 16 orang (40\%), 23 orang $(57,5 \%)$, dan 1 orang (2,5\%) tidak setuju bahwa di dalam teks cerita rakyat terdapat banyak pemebelajaran yang dapat di ambil dan diimplementasikan dalam kehidupan. 18 orang (45\%) sangat setuju dan 22 orang (55\%) setuju bahwa cerita rakyat dapat membentuk karakter seseorang melalui nilai-nilai moral dan spiritual yang terkandung di dalam cerita rakyat. Hal ini sesuai dengan pendapat Teeuw (dalam Amin, I, \& Syahrul R, 2013), bahwa sastra oral memang masih berfungsi sebagai sarana komunikasi langsung dalam masyarakatnya, sehingga dalam masyarakat untuk menyampaikan keinginan dan harapan bisa berbentuk cerita rakyat. Fungsi cerita rakyat bagi masyarakat adalah: (a) menyadarkan manusia 
bahwa ada kekuatan gaib, (b) memberikan jaminan masa kini, dan (c) memberikan pengetahuan pada dunia. Fungsi sosial cerita rakyat ini dipertegas lagi oleh Hasanuddin WS (dalam Amin, I,. \& Syahrul R, 2013) yang menguraikan bahwa fungsi sosial cerita rakyat bagi kehidupan dalam masyarakat adalah untuk mengembangkan integritas masyarakat, alat kontrol sosial, memadukan kekuatan kebersamaan yang terpecah untuk solidaritas sosial, identitas kelompok, dan harmonisasi komunal.

Dari 40 responnden, 8 orang (20\%) sangat setuju, 30 orang (75\%) setuju, dan 2 orang (5\%) tidak setuju bahwa di dalam teks prosedur terdapat kata imperatif atau kata perintah untuk melakukan apa yang dibahas pada teks agar si pembaca melakukan apa yang diperintahkan pada isi teks tersebut. 13 orang (32,5\%) sangat setuju, 26 orang (65\%) setuju, dan 1 orang $(2,5 \%)$ tidak setuju bahwa teks prosedur sangat dibutuhkan di dalam kehidupan sehari-hari untuk mengetahui langkah-langkah dalam memperbaiki atau membuat sesuatu. Hal ini sesaui dengan pendapat Arviyana, M., Syahrul, \& T (2013), teks prosedur merupakan suatu langkah-langkah dan tujuan yang harus diikuti agar suatu pekerjaan dapat dilakukan. Teks prosedur membantu mengetahui cara-cara melakukan aktifitas tertentu dan kebiasaan hidup yang benar. Selain itu, membantu dalam menggunakan alat dengan benar tanpa membahayakan diri dan tanpa merusak alat itu sendiri.

Dari 40 rsponden, 9 orang (22,5\%) sangat setuju, 30 orang (75\%) setuju, dan 1 orang $(2,5 \%)$ tidak setuju bahwa dalam menyampaikan argumen atau pendapat tidak selalu dengan lisan, tetapi juga dapat melalui tulisan teks argumentasi. 8 orang (20\%) sangat setuju, 23 orang $(27,5 \%)$ setuju, dan 9 orang $(22,5 \%)$ tidak setuju dalam menulis teks eksposisi saya sering mengalami kesalahan dalam ejaan dan komposisi penulisan teks. Menururut Priyatni dan Harsiati (dalam Amalia, F. \& R, Syahrul,. 2018), menyatakan bahwa teks eksposisi adalah teks yang memuat suatu isu atau persoalan tentang topik tertentu dan pernyataan yang menunjukkan posisi penulis dalam menanggapi persoalan tersebut. Menurut kemendikbud (dalam Amalia, F., R, Syahrul, 2018), teks eksposisi memiliki fungsi sosial yaitu mengusulka pendapat pribadi mengenai sesuatu. Sedangkan argumentasi Menurut Parera (dalam A, Syahrul, \& Ratna, 2012), merupakan karangan eksposisi khusus. Melalui argumentasi, penulis berusaha untuk menyakinkan dan membujuk pembaca agar percaya dan menerima apa yang dikemukakan penulis. 
Keterampilan menulis teks anekdot adalah sebuah keterampilan dalam menulis teks yang menghibur dan bersifat lucu yang bertujuan untuk mengkritik seseorang. Menurut Wardani (dalam Mayora, Syahrul, \& Tressyalina, 2018), menyatakan bahwa teks anekdot merupakan sebuah cerita singkat, namun lucu dan isinya berupa sindiran. Senada dengan pendapat di atas, Nuryatin (dalam Mayora, Syahrul, \& Tressyalina, 2018), menyatakan bahwa anekdot adalah sebuah cerita lucu atau menggelitik yang bertujuan memberikan suatu pelajaran tertentu. Berdasarkan hal itu Dari 40 responden, 13 orang (32,5\%) sangat setuju dan 27 orang (67,5\%) setuju berpendapat bahwa dalam menulis teks anekdot diperlukan keterampilan bahasa yang kreatif dan efektif atau retorik. 7 orang (17,5\%) sangat setuju, 29 orang (72,5\%) setuju, dan 4 orang (10\%) tidak setuju teks anekdot adalah sebuah keterampilan dalam menulis teks yang menghibur dan bersifat lucu yang bertujuan untuk mengkritik seseorang. 4 orang (10\%) sangat setuju, 31 orang $(77,5 \%)$ setuju, 4 orang (10\%) tidak setuju, dan 1 orang $(2,5 \%)$ sangat tidak setuju jika dalam menyindir masalah politik dapat dilakukan dengan cara membuat teks anekdot. 12 orang (30\%) sangat setuju dan 28 orang (70\%) setuju jika berdasarkan kegiatan yang dilakukan sehari-hari seseorang dapat membuat sebuat teks narasi. Berdasarkan hal tersebut dengan teks narasi seseorang dapat meningkatkan keterampilan menulis dengan menuliskan kegiatan yang telah dilakukan sehari-hari, begitu juga dengan teks-teks yang lain. Sehingga bahasa dapat diwujudkan dalam teks, yang biasa disebut dengan bahasa tulis. 


\section{Daftar Rujukan}

A, D. Y., Syahrul, R., \& Ratna, E. (2012). PENINGKATAN KETERAMPILAN MENULIS ARGUMENTASI SISWA KELAS X SMK N 1 BATUSANGKAR, 1(1).

Amin, I,. Syahrul R, E. (2013). CERITA RAKYAT PENAMAAN DESA DI KERINCI:

Kategori dan Fungsi Sosial Teks. Journal of Chemical Information and Modeling, 1(1). https://doi.org/10.1017/CBO9781107415324.004

Arviyana, M. Syahrul, . T. (2013). Pengaruh Model Discovery Learning Berbantuan Media Audiovisual Terhadap Keterampilan Menulis Teks Prosedur Siswa Kelas Vii Smp Negeri 12 Padang, 7(1).

Diah, K., \& Wulandari, A. (2015). Peranan Bahasa dalam Pengembangan Ilmu Pengetahuan.

Fitri Amalia, R Syahrul, E. A. (2018). PENGARUH MODEL DISCOVERY LEARNING BERBANTUAN MEDIA AUDIOVISUAL TERHADAP KETERAMPILAN MENULIS TEKS EKSPOSISI SISWA KELAS VIII SMP NEGERI 31 PADANG. Jurnal Pendidikan Bahasa Dan Sastra Indonesia, 7(1).

Mayora, Syahrul, \& Tressyalina. (2018). PENGARUH MODEL DISCOVERY LEARNING BERBANTUAN MEDIA AUDIOVISUAL TERHADAP KETERAMPILAN MENULIS TEKS ANEKDOT SISWA KELAS X SMA NEGERI 1 LEMBAH GUMANTI KABUPATEN SOLOK. Jurnal Pendidikan Bahasa Dan Sastra Indonesia, 6(2).

Suardi, I. P., Ramadhan, S., \& Asri, Y. (2019). Pemerolehan Bahasa Pertama pada Anak Usia Dini. Jurnal Obsesi : Jurnal Pendidikan Anak Usia Dini, 3(1), 265. https://doi.org/10.31004/obsesi.v3i1.160 